\title{
Was Y2K Behind the Business Investment Boom and Bust?
}

\author{
Kevin L. Kliesen
}

$\triangle$ ccording to the Business Cycle Dating Committee of the National Bureau of Economic Research, the nation's recordlong business expansion ended in March 2001, exactly 10 years after it started. Much of the downturn in the growth of U.S. economic activity during 2001 can be traced to a sharp decline in business purchases of information processing equipment and software, otherwise known as high-tech capital goods. This investment bust came on the heels of a boom in spending on those same types of capital goods over the latter part of the 1990s. Although business fixed investment spending tends to be pro-cyclical, this time the boom and bust was unusually large. One explanation for the boom and bust that has not been explored in much detail was the surge in business purchases of hardware and software in preparation for the century date change (hereafter, Y2K). Was the boom due to efforts by firms to upgrade their computer hardware and software? Likewise, was the bust caused by the cessation of Y2K-related capital spending?

\section{RECENT TRENDS IN BUSINESS FIXED INVESTMENT SPENDING}

In the national income and product accounts (NIPA), nonresidential investment (or business fixed investment [BFI]) comprises investment in structures and investment in equipment and software (E\&S). Over the past 25 years, fixed investment in structures as a share of total BFI has dropped from about 33 percent to 27 percent, so that, accordingly, business investment in $\mathrm{E} \& \mathrm{~S}$ as a share of BFI has grown from about 67 percent to about 73 percent. Figure 1 shows that there has been a marked shift in the composition of $E \& S$ investment since $1977 .{ }^{1}$ Business expenditures on $\mathrm{E} \& S$ investment are classified under four categories: (i) information processing equipment

Kevin L. Kliesen is an economist at the Federal Reserve Bank of St. Louis The author thanks Dave Wasshausen of the Bureau of Economic Analysis and Robert Parker of the General Accounting Office for helpful comments. Thomas A. Pollmann provided research assistance.

(C) 2003, The Federal Reserve Bank of St. Louis. and software (IPES), (ii) transportation equipment, (iii) industrial equipment, and (iv) other. In 1977 , each amounted to roughly 17 percent of total BFI. By mid-2000, IPES investment as a share of BFI had grown to a little less than 36 percent, while the remaining components had smaller shares than they did in 1977.

Figure 2 shows that increased spending on software accounted for the bulk of the increase in IPES investment spending. From 1977 to late 2001, the share of software investment rose from a little more than 15 percent to nearly 47 percent. Over this period, the share of fixed investment in computers rose markedly less, from about 15 percent to about 18 percent.

In terms of its contribution to real GDP growth, the investment boom in the high-tech sector was largely a phenomenon of the late 1990s. Real IPES investment grew at a little more than 12 percent per year from 1990 to 1995. This rate of growth accelerated to a little more than 19 percent per year from 1995 to 2000, so that by the fourth quarter of 2000 it was at an all-time high as a share of BFI (Figure 1). Not surprisingly, the contribution to real GDP growth from IPES, as seen in Table 1, increased measurably during the latter half of the 1990s. From 1990 to 1995, growth of BFI contributed 0.4 percentage points of the 2.3 percent growth per year of real GDP. From 1996 to 2000, though, the contribution of real BFI jumped to 1.2 percent per year, a bit less than a third of the 4.0 percent per year growth of real GDP. During this period, the largest contribution to real BFI growth stemmed from E\&S investment (averaging 1.0 percentage points). The contribution from business structures, industrial, and transportation equipment was relatively small.

Beginning in the second half of 2000 , businesses started to scale back their purchases of most types of capital goods-not just high-tech equipment and software (IPES). Indeed, over the four quarters

\footnotetext{
1 Because chain weights do not have the additive and multiplicative properties of fixed weights, it is not correct to express shares in real terms. Thus, Figure 1 expresses shares in current (nominal) dollars. See Whelan (2000)
} 


\section{Figure 1}

\section{E\&S Investment as a Share of Nonresidential Fixed Investment}

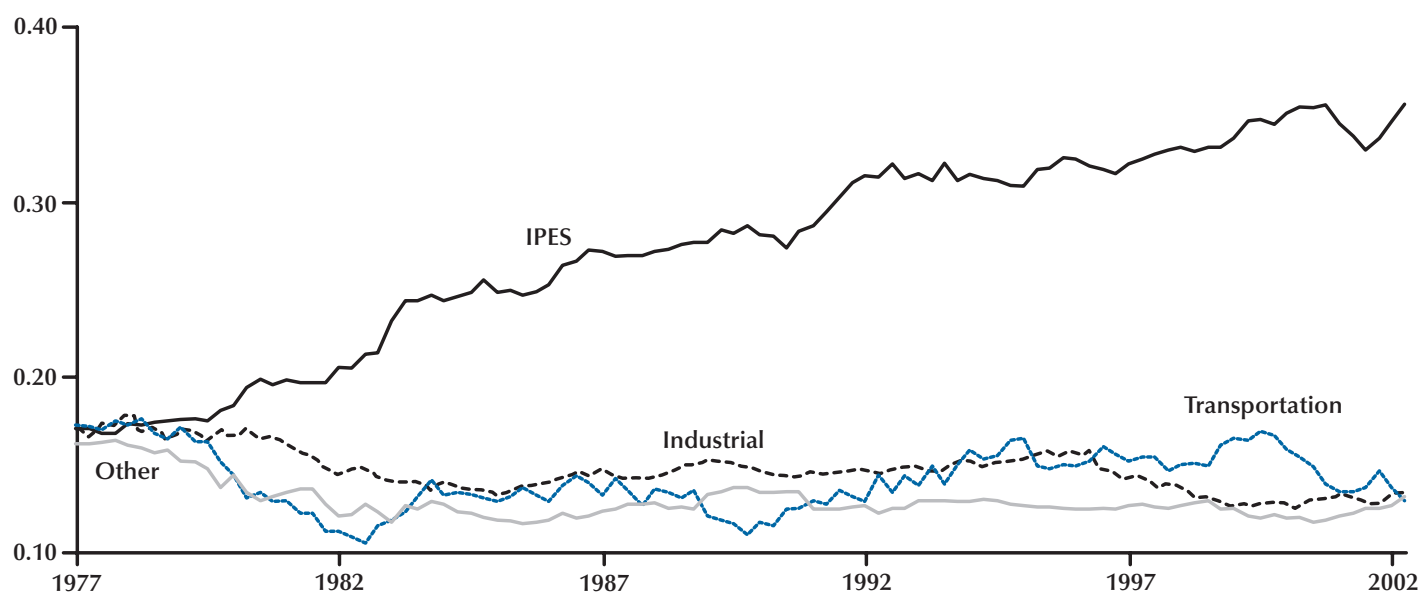

NOTE: Shares expressed in current (nominal) dollars.

\section{Figure 2}

\section{Composition of IPES Fixed Investment}

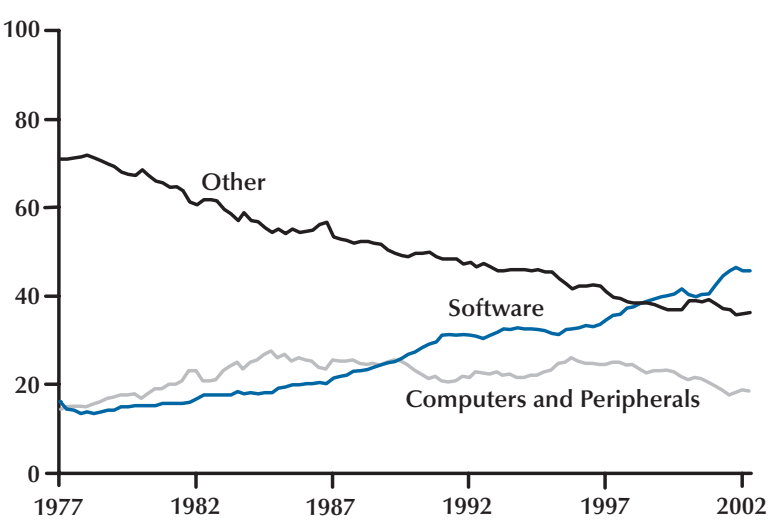

NOTE: Shares expressed in current (nominal) dollars.

of 2001, real fixed investment in business structures fell 10.6 percent, about the same as the decline in IPES investment (10.5 percent); real investment in $\mathrm{E} \& \mathrm{~S}$ fell less, roughly 9 percent. As seen in Table 1, of the 3.7-percentage-point decline in real GDP growth from 1996-2000 to 2001, nearly half (1.6 percentage points) stemmed from the swing in $E \& S$ investment, with IPES investment comprising the bulk of that (1 percentage point).

\section{CONVENTIONAL EXPLANATIONS OF THE INVESTMENT BOOM AND BUST}

Firms will invest (i.e., purchase capital equipment) in order to increase their future profit opportunities. Hence, a firm's decision to invest will depend on its projection of those future profit opportunities (expected future returns) and the cost of making the investment (cost of capital). In terms of explaining the recent investment boom and bust, it might be useful to consider two competing explanations. One explanation is that the investment boom may have simply been a cyclical phenomenon. That is, expected returns to investment rose as economic growth accelerated. Moreover, rapidly advancing technology and declining prices of information technology goods lowered the cost of capital for high-tech capital goods relative to other capital goods, boosting investment in information processing and communications equipment.

Another explanation suggests that the investment bust came about as aggregate demand growth weakened in 2000 and 2001 in response to the sharp declines in equity prices, especially those of technology stocks. Second, expected returns during the latter part of the 1990s may have risen because of problems associated with Y2K. That is, the opportunity cost of not fixing potential computer and software problems was high. Failure to fix the problems may have resulted in disruptions to business activity and, hence, lower profits. Once these Y2K 


\section{Table 1}

\section{Real BFI Contributions to Real GDP Growth (Percentage Points)}

\begin{tabular}{|c|c|c|c|c|c|}
\hline & 1970-79 & 1980-89 & 1990-95 & 1996-2000 & 2001 \\
\hline Real GDP Growth & 3.3 & 3.0 & 2.3 & 4.0 & 0.3 \\
\hline \multicolumn{6}{|l|}{ Contributions from: } \\
\hline Nonresidential fixed investment & 0.6 & 0.4 & 0.4 & 1.2 & -0.7 \\
\hline Structures & 0.1 & 0.1 & -0.1 & 0.2 & -0.1 \\
\hline Equipment and software & 0.5 & 0.3 & 0.5 & 1.0 & -0.6 \\
\hline Information processing & 0.3 & 0.4 & 0.3 & 0.7 & -0.3 \\
\hline Computers and peripherals & 0.1 & 0.2 & 0.2 & 0.3 & 0.0 \\
\hline Software & 0.0 & 0.1 & 0.1 & 0.2 & 0.0 \\
\hline Other & 0.1 & 0.1 & 0.1 & 0.2 & -0.2 \\
\hline Industrial equipment & 0.1 & 0.0 & 0.0 & 0.1 & -0.1 \\
\hline Transportation equipment & 0.1 & 0.0 & 0.1 & 0.1 & -0.2 \\
\hline Other & 0.1 & 0.0 & 0.0 & 0.1 & 0.0 \\
\hline
\end{tabular}

NOTE: Percentages are averages of years indicated (subject to rounding errors).

problems were addressed, the expected returns were zero and these types of investment ceased.

\section{Was There Excess Investment During the 1990s?}

The substantial decline in investment spending beginning in late 2000-both high-tech and nonhigh-tech-led some to conclude that firms overinvested in capital goods during the latter part of the 1990s. ${ }^{2}$ Excess investment is usually thought of as the amount of capital goods (in the aggregate) that exceeds the amount that businesses require to produce the existing demand for goods and services. In the context of the firm's investment decision noted above, it is useful to think of excess investment as the result of firms overestimating future profit opportunities (expected returns) in the present relative to the existing cost of capital. During the latter half of the 1990s and into early 2000, excess investment may have occurred because firms expected the rapid rate of aggregate growth to persist longer than it did.

Figure 3 provides some evidence that there may have been excess business investment in IPES. In Figure 3, the levels of real IPES investment are indexed to 100 for each of the post-World War II

\footnotetext{
2 In some circles, this was termed a "capital overhang." See Council of
} Economic Advisers (2002) or French, Klier, and Oppedahl (2002).

\section{Figure 3}

\section{Real IPES}

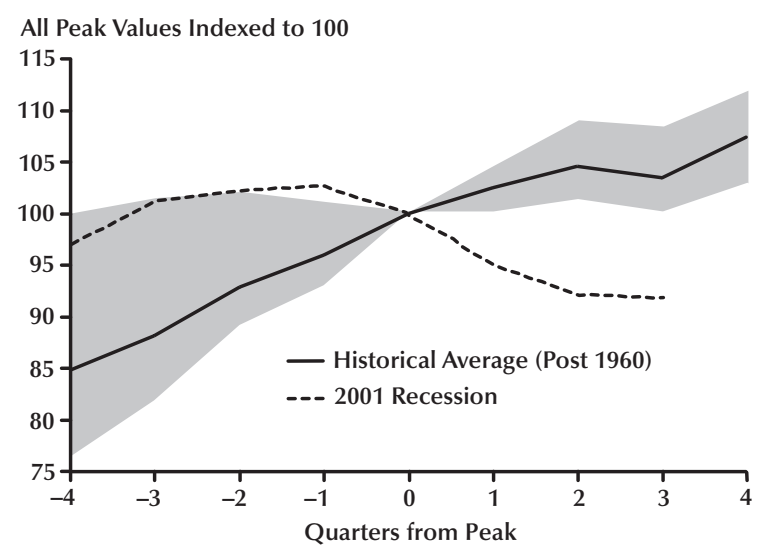

NOTE: The shaded area represents the range of previous recessions.

business cycle peaks (excluding the 1980 and 2001 peaks). The average of these indexed levels is plotted (solid line), as is the indexed level for the most recent period (2000-01)(dotted line). Relative to previous peaks (as defined by the National Bureau of Economic Research), IPES investment was exceptionally strong just before the 2001 recession, 


\section{Table 2}

Was There Excess Investment During the 1991-2001 Expansion? (Percentage Deviations from Trend)

\begin{tabular}{|c|c|c|c|c|c|}
\hline Expansion period & $\begin{array}{c}\text { Business } \\
\text { structures }\end{array}$ & IPES & $\begin{array}{c}\text { Industrial } \\
\text { equipment }\end{array}$ & $\begin{array}{c}\text { Transportation } \\
\text { equipment }\end{array}$ & Residential \\
\hline \multicolumn{6}{|l|}{ 1961:Q2 to 1969:Q4 } \\
\hline Average deviation & -0.44 & -0.97 & -0.87 & 0.17 & -0.73 \\
\hline High & 8.56 & 10.59 & 9.48 & 13.07 & 13.23 \\
\hline Low & -8.55 & -9.98 & -13.90 & -15.08 & -22.99 \\
\hline High - Low & 17.11 & 20.58 & 23.39 & 28.15 & 36.22 \\
\hline \multicolumn{6}{|l|}{ 1970:Q4 to 1973:Q4 } \\
\hline Average deviation & 1.07 & 1.45 & -3.29 & -1.25 & 8.40 \\
\hline High & 8.77 & 9.29 & 11.74 & 16.11 & 18.41 \\
\hline Low & -3.46 & -5.41 & -12.01 & -32.48 & -8.64 \\
\hline High - Low & 12.23 & 14.70 & 23.74 & 48.59 & 27.05 \\
\hline \multicolumn{6}{|l|}{ 1975:Q1 to 1980:Q1 } \\
\hline Average deviation & -3.48 & -3.23 & -1.66 & -0.26 & 0.03 \\
\hline High & 5.64 & 4.09 & 9.11 & 16.58 & 15.43 \\
\hline Low & -10.03 & -13.34 & -9.26 & -23.53 & -35.85 \\
\hline High - Low & 15.66 & 17.43 & 18.37 & 40.12 & 51.28 \\
\hline \multicolumn{6}{|l|}{ 1982:Q4 to 1990:Q3 } \\
\hline Average deviation & -0.40 & 0.86 & -0.20 & 0.44 & 2.04 \\
\hline High & 8.48 & 7.99 & 8.89 & 8.96 & 8.29 \\
\hline Low & -14.77 & -15.28 & -16.41 & -19.93 & -29.61 \\
\hline High - Low & 23.25 & 23.26 & 25.30 & 28.89 & 37.91 \\
\hline \multicolumn{6}{|l|}{ 1991:Q1 to 2001:Q1 } \\
\hline Average deviation & -1.01 & -0.95 & -1.04 & -0.97 & -1.33 \\
\hline High & 5.65 & 4.77 & 4.86 & 10.06 & 8.13 \\
\hline Low & -6.45 & -6.17 & -9.27 & -15.69 & -20.73 \\
\hline High - Low & 12.10 & 10.94 & 14.13 & 25.75 & 28.86 \\
\hline
\end{tabular}

NOTE: Percentages are calculated as deviations from trend in chain-weighted dollars. The trend value is estimated from the HodrickPrescott algorithm. See footnote 5. Sample period for Hodrick-Prescott calculations is 1947:Q1 to 2001:Q1 for all categories except IPES, which begins in 1959:Q1.

before falling off considerably. ${ }^{3}$ In fact, the figure suggests that the high-tech investment boom and bust of 2001-02 was the largest in the post-World War II period.

There are other ways to ascertain whether there was excess investment toward the end of the 19912001 expansion. One method is to compare the desired aggregate capital stock to the actual capital

3 IPES data are available only back to 1959 at a quarterly frequency. Calculations exclude the short 1980 recession. stock (the linkage between the two, of course, is investment spending). A difficulty with this approach is that the desired capital stock can only be estimated from an econometric model. ${ }^{4}$ Another method of ascertaining whether excess investment occurred is to calculate the percentage deviation of the actual

\footnotetext{
4 Macroeconomic Advisers (2002) found that the actual stock of IPES capital exceeded the desired stock by a little more than 6 percent during the fourth quarter of 2000 (the largest deviation of the 1991-2001 expansion). This estimate was calculated prior to the 2002 annual revisions of the NIPA data.
} 
level of real fixed investment from the trend level. 5 Table 2 shows these percentage deviations for real fixed investment in business structures, IPES, industrial equipment, transportation equipment, and residential investment for each U.S. business expansion since 1960.

One aspect of the typical business expansion that is seen from Table 2 is that real investment is highly volatile. This is illustrated by the difference between the high and low percentage deviations from trend (at a quarterly frequency). In the 1982-90 expansion, for example, real IPES investment relative to its trend ranged from -15.3 percent to +8.0 percent. Even larger percentage deviations from trend were seen in previous expansions and among other forms of fixed investment. Thus, if a large, positive percentage deviation from trend is viewed as a sign of excess investment, excessive investment during the 1991-2001 expansion was atypical in that it was comparatively mild. The largest positive deviation occurred in transportation equipment (10.1 percent). This was relatively small compared with the deviation in the 1961-69, 1970-73, and 1975-80 expansions, but it exceeded the deviation in the 1982-90 expansion. For the 1991-2001 expansion, positive deviations from trend of similar size were noted in business structures, industrial equipment, and residential fixed investment. Thus, it does not appear that excess IPES investment was particularly noteworthy. The largest positive percentage deviation from trend occurred in the second quarter of 2000 , but it was small (4.77 percent) compared with previous expansions, such as the 1961-69 (10.59 percent) and 1982-90 (7.99 percent) expansions.

While the evidence from Table 2 suggests that the investment boom in the 1990s was not excessive, the data from Table 1 nonetheless show that the surge in BFI spending contributed appreciably to real GDP growth. One popular explanation for the recent investment boom is the acceleration in labor productivity growth beginning around 1995, which some have dubbed the "New Economy" story and which ties in with the rise in corporate equity prices in the latter half of the 1990s. ${ }^{6}$

\footnotetext{
5 The trend was calculated using the Hodrick-Prescott filter, a statistical smoothing algorithm used to estimate the long-term trend component of a time series. The Hodrick-Prescott filter removes movements that are thought to arise merely from changes associated with the business cycle. The calculation here was done in EViews Version 4.0.

6 See Greenspan (1998).
}

\section{The New Economy Story}

Beginning around 1995, prices for computers and peripherals began to fall sharply. After falling an average of 12.8 percent per year from 1990 to 1994 (annual data), computer prices fell an average of 24.1 percent per year from 1995 to 1999 . Bolstered by falling prices, expenditures (output) on high-tech capital goods rose sharply. ${ }^{7}$ From 1995 to 2000 (annual data), production of high-tech equipment rose an average of roughly 40 percent per year, after growing an average of a little more than 21 percent per year from 1990 to $1995 .^{8}$ The increased amount of high-tech capital equipment available to workers (capital deepening) raised their labor productivity. ${ }^{9}$

A potential key impetus behind the investment boom during this period was the sharp rise in corporate equity prices. All else equal, rising equity prices lower the (equity) cost of capital, which, by lowering the hurdle rate that separates profitable from unprofitable investments, spurs firms to increase their level of fixed capital investment (and output). Figure 4 indicates that corporate equity prices during the late 1990s rose the most among those publicly traded firms generally thought of as both users and producers of information technology (IT) capital goods such as computers, semiconductors, and software. From October 8, 1998, to March 10, 2000, the technology-heavy Nasdaq composite index rose nearly 260 percent to just under 5050 . Over the same period, the Wilshire 5000 index rose from about 8,621 to a little more than 13,952, an increase of about 62 percent; while noteworthy, this increase is a far cry from 260 percent. The larger increase in the Nasdaq composite index (decline in the cost of

\footnotetext{
7 Pakko (2002) tackles the thorny issue of whether improvement in the quality of high-tech capital goods-as reflected in the sharp declines in relative prices of computers and other information technology equipment-was overstated. If true, this would overstate the growth of real capital spending. He finds that generally not to be the case.

8 High-tech is defined as non-energy output of computers, communications equipment, and semiconductors. See the Federal Reserve Board's G. 17 statistical release (Industrial Production and Capacity Utilization).

9 Surveying five prominent studies, Stiroh (2002) found that the contribution of IT-related investment-both the production and use of IT capital goods-explained a substantial portion of the roughly 1percentage-point acceleration in the growth of labor productivity from 1973-95 (1.4 percent) to 1995-99 (2.4 percent). These studies use a production-function framework to estimate the contribution of the change in labor productivity growth stemming from (i) capital deepening, (ii) labor quality, and (iii) total factor productivity. Three of the five studies found that the dominant contribution arose from an acceleration in total factor productivity growth that was largely due to IT-related effects.
} 


\section{Figure 4}

\section{Nasdaq and Wilshire 5000 Equity Market Indices}

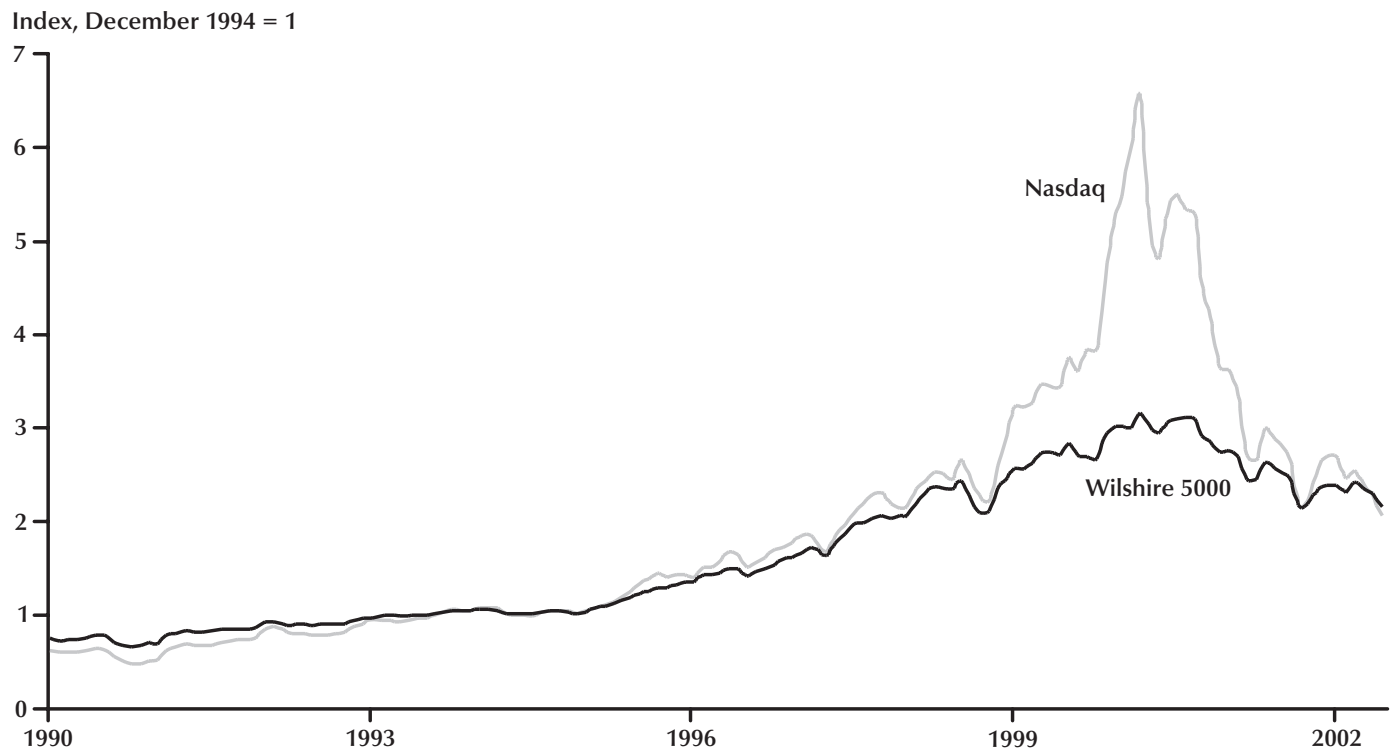

capital) relative to the Wilshire 5000 index is consistent with the figures reported in Table 1, which show that the acceleration in BFI was the largest in the IPES segment.

Beginning in March 2000, markets began to reassess their estimates of future profitability in the IT sector. This is seen by the steep decline in the Nasdaq composite index in Figure 4. By September 10, 2001, the Nasdaq had fallen to just under 1,700, giving up most of the gains seen over the past three years. As the equity cost of capital in the IT sector began to rise sharply, demand for high-tech goods began to wane. Accordingly, manufacturers of hightech capital goods began to scale back production: From October 2000 to September 2001, output of IT capital goods fell 16 percent. And since (nominal) investment in business $E \& S$ had risen to about 10 percent of GDP in 2000, the subsequent fall in the demand for these products led to a sharp deceleration in output growth (see Table 1).

As seen in Figure 5, the Nasdaq composite index peaked much earlier (March 2000) than did production of high-tech capital spending (December 2000), though the growth of high-tech output began to decelerate markedly in May. Although the timing suggests that the plunge in the Nasdaq may have been a significant factor behind the high-tech investment bust, it does not readily explain the decline in non-high-tech investment spending. ${ }^{10}$ Although the Wilshire 5000 index also peaked in March 2000, real BFI in transportation equipment peaked much earlier, in the third quarter of 1999 , while real fixed investment in structures peaked in the fourth quarter of 2000 and industrial equipment during the first quarter of 2001.

McCarthy (2001) attempted to ascertain whether falling equity prices could explain the investment boom and bust in E\&S (a mix of high-tech and nonhigh-tech capital goods). To test this hypothesis, McCarthy used a series of one-step-ahead forecasts (from the first quarter of 1995 to the second quarter of 2001) derived from a standard neoclassical model of business investment, which was augmented with a measure of equity market valuation (Tobin's $Q$ ). He found that the model did a reasonably good job of predicting the growth of real $E \& S$ fixed investment spending from 1995 into early 2000. ${ }^{11}$ Beginning in mid-2000, though, the model substantially underpredicted the falloff in capital spending. Using a counterfactual exercise that assumed equity values grew from 1995 onward at their 1980-94 pace, he

\footnotetext{
${ }^{10}$ Moreover, recall from the discussion of Table 2 that the largest percentage deviation of IPES investment from trend occurred in the second quarter of 2000.

11 McCarthy's estimates were derived prior to the July 2002 annual NIPA revisions.
} 


\section{Figure 5}

\section{Nasdaq Composite Index and Output of Selected High-Tech Industries}

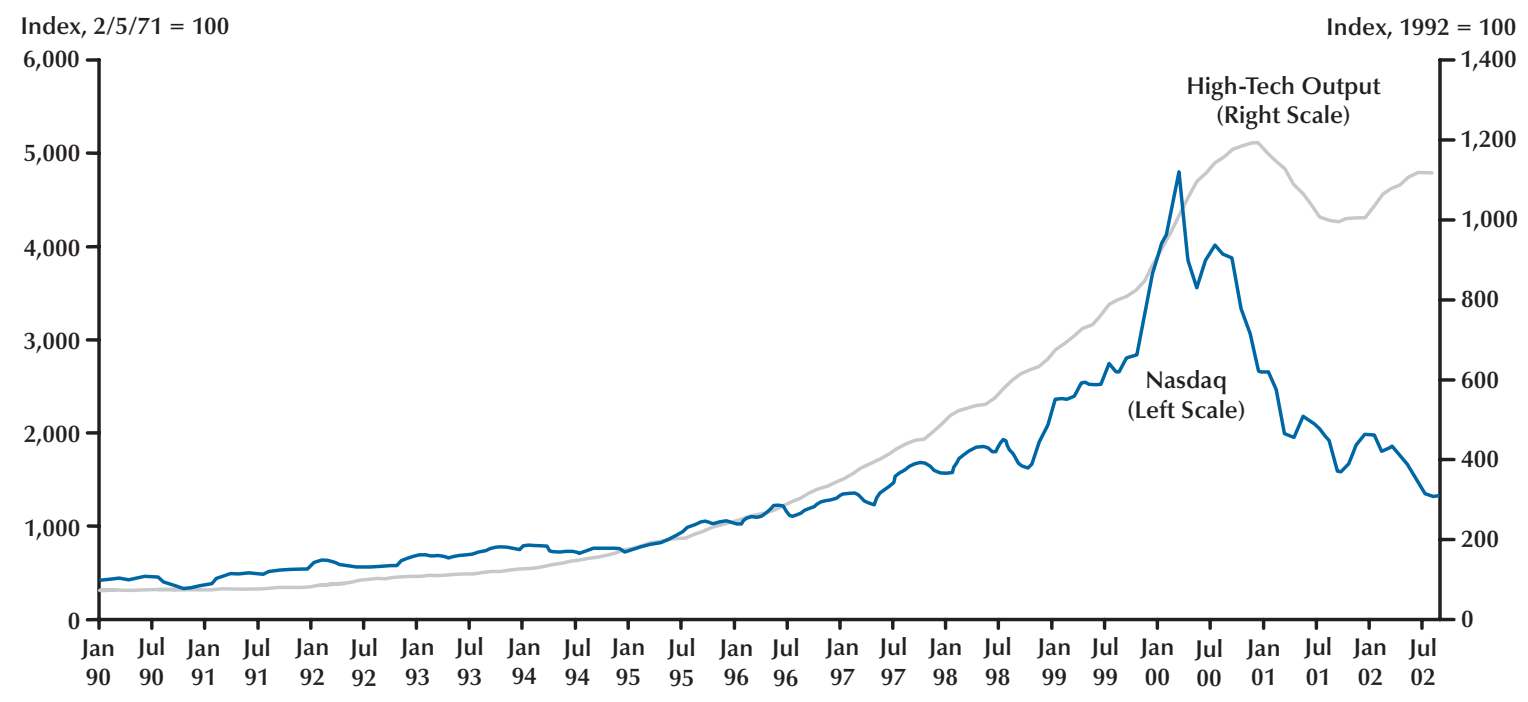

found that the model predicted $E \& S$ investment would have still grown at a double-digit pace, but that the drop in equity prices exerted some drag on fixed investment growth. In particular, he found that real E\&S investment growth would have been about 4 percentage points higher if the stock market had not fallen as it did. ${ }^{12}$ Furthermore, McCarthy found a larger effect from the sharp drop in equipment prices over the latter half of the 1990s, which he attributes to weak demand. If so, then one potential source of weak demand may have been the end of the expenditures by businesses to fix the so-called Y2K computer bug.

\section{CAN Y2K EXPLAIN THE INVESTMENT BOOM AND BUST?}

One explanation of the high-tech investment boom and bust that has received relatively scant attention centers on the surge in spending by private businesses to ready themselves for $\mathrm{Y} 2 \mathrm{~K} .{ }^{13} \mathrm{The}$ "Y2K problem," as it was called, was viewed by some government entities as "potentially extremely seri-

\footnotetext{
12 McCarthy also ran a counterfactual exercise that assumed relative prices of $E \& S$ capital goods from 1995 onward fell at a constant rate equal to their 1980-94 average. In this counterfactual forecasting exercise, he found that the model does a better job of forecasting the investment bust in 2000-01

13 The 2002 Economic Report of the President states on p. 36 that some of the 2000-01 slowdown reflected the "lingering effects" of Y2K.
}

ous," given the computer's predominant role in large industrialized economies. ${ }^{14}$ According to industry figures cited by the U.S. Department of Commerce in July 1998, almost 90 percent of all firms with fewer than 2,000 employees had not started Y2K "remediation projects" as of 1997. Moreover, nearly half of all personal computers shipped in 1997 were not Y2K compliant. ${ }^{15}$ Some economists went so far as to predict a "severe" global recession, arising from widespread disruptions to, for example, the air transportation system, electrical grids, the financial infrastructure, and government services. ${ }^{16}$ To prevent these disturbances from materializing, the private sector began to devote a considerable amount of resources to fixing the problem. One manifestation of this was the upsurge in payroll employment in computer and data processing services. As seen in Figure 6, year-over-year growth throughout much of 1999 was quite strong, reaching nearly 17 percent in August. This rapid growth, however, was not historically large, as evidenced by the much stronger growth seen during the late 1970s and early 1980s.

Public policymakers were also devoting con-

\footnotetext{
${ }^{14}$ Council of Economic Advisers (1999, p. 77).

15 Bachula (1998).

${ }^{16}$ Edward Yardeni, now at Prudential Securities, was the chief alarmist on the Y2K issue. See Matthews (1998)
} 


\section{Figure 6}

\section{Employment Growth in Computer and Data Processing Services}

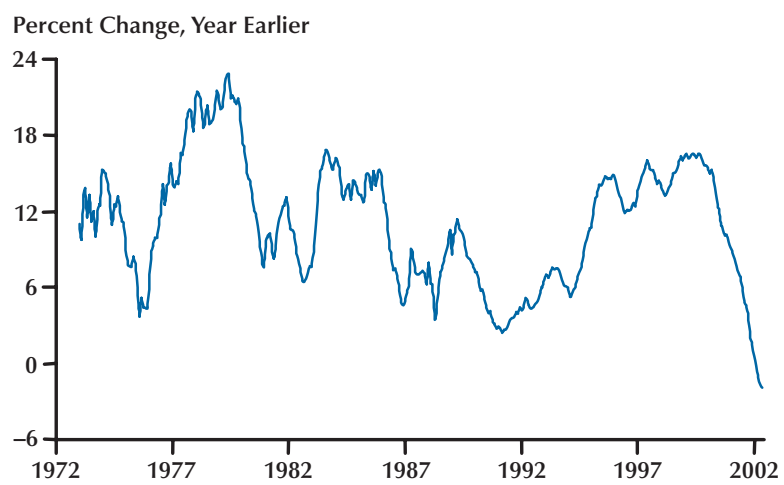

SOURCE: U.S. Bureau of Labor Statistics.

siderable time and resources to minimizing the $\mathrm{Y} 2 \mathrm{~K}$ problem. The Federal Reserve System, anticipating a precautionary surge in the demand for cash by households, formulated a "temporary financing facility" designed to ensure that sufficient liquidity existed for the banking system around the time of the century date change. Part of this effort included a large increase in the supply of currency to depository institutions. ${ }^{17}$

Perhaps because of the preventative efforts undertaken by the public and private sector beforehand, most forecasters evidently were of the opinion that the Y2K problem would not be a significant macroeconomic event. Still, some precautionary spending was expected to occur. According to the panel of Blue Chip forecasters in July 1999, real GDP growth in the second half of 1999 was expected to be boosted by a buildup of business inventories by firms and an upswing in purchases of nondurable goods by households. This effect was expected to be relatively small, though: In the May 1999 Survey of Professional Forecasters, nearly 60 percent of forecasters expected the assorted $\mathrm{Y} 2 \mathrm{~K}$ effects to boost real GDP growth by 0.1 to 0.5 percentage points in 1999. In 2000, as these temporary effects reversed, about half of the forecasters expected an effect on real GDP growth of between 0.0 and -0.4

17 See the minutes of the August 24, 1999, meeting of the Federal Open Market Committee (<www.federalreserve.gov/fomc/minutes/ 19990824.htm >). From the week ending December 1, 1999, to the week ending February 2, 2000, surplus vault cash jumped from $\$ 17.4$ billion to $\$ 40.5$ billion. As a share of total vault cash, surplus cash surged to an all-time high of just over 50 percent. percentage points. The net effect was expected to be essentially zero, and, at first glance, the end-ofyear Y2K disruptions to the aggregate economy turned out to be minimal.

The alarmists turned out to be wrong about a Y2K-inspired worldwide depression; nevertheless, the high-tech investment boom and bust shortly before and after the century date change suggests some causality. Table 3, which replicates the HodrickPrescott framework of Table 2 , indicates that the investment bust - as seen by the largest negative percentage deviation from trend (low) - was especially large for IPES. During the 2001 recession, IPES investment at one point was 13.68 percent below trend, which was surpassed only by the severe 1981-82 recession. The average deviation of IPES investment during the 2001 recession ( -7.22 percent), however, was much larger than in the previous recessions listed. Table 3 also shows (compared with previous recessions) a large negative deviation for transportation equipment (-10.5 percent), but not for industrial equipment ( -2.95 percent) or residential fixed investment ( -1.88 percent).

The evidence in Table 2 shows that the largest positive deviation in real IPES investment spending from trend during the 1991-2001 expansion was not unusually large (compared with previous expansions). This finding suggests that $\mathrm{Y} 2 \mathrm{~K}$ spending was probably not that significant during the investment boom. However, the evidence from Table 3 is at least consistent with the conjecture that a cessation of business spending on $\mathrm{Y} 2 \mathrm{~K}$ fixes may have exacerbated the sharp decline in IT investment spending. To see whether the end of Y $2 \mathrm{~K}$ was responsible for the high-tech investment bust, it will be useful to look at the estimated amount of Y2K outlays by businesses that flowed into the NIPA.

\section{Accounting Issues: How Does Y2K Spending Map into the NIPA?}

Given the remediation efforts noted above, it seems probable that firms replaced a significant amount of their stock of computers and software, and spent a considerable amount of resources to fix existing source code, in an effort to avoid disruptions at the century date change. To see how difficult estimating the direct result of Y2K-related spending in the NIPA is, consider three different scenarios by which Firm A could have undertaken its Y2K fix.

Scenario 1. In the first scenario, suppose that Firm A paid Firm B $\$ 10$ million to make its 


\section{Table 3}

Where Was the Investment Bust During the 2001 Recession? (Percentage Deviations from Trend)

\begin{tabular}{|c|c|c|c|c|c|}
\hline Recession period & $\begin{array}{l}\text { Business } \\
\text { structures }\end{array}$ & IPES & $\begin{array}{l}\text { Industrial } \\
\text { equipment }\end{array}$ & $\begin{array}{c}\text { Transportation } \\
\text { equipment }\end{array}$ & Residential \\
\hline \multicolumn{6}{|l|}{ 1960:Q2 to 1961:Q1 } \\
\hline Average deviation & 1.90 & 3.83 & 2.53 & -4.22 & -6.44 \\
\hline High & 3.55 & 7.88 & 11.74 & 5.35 & -2.28 \\
\hline Low & 0.67 & -3.60 & -7.35 & -16.14 & -8.76 \\
\hline High - Low & 2.88 & 11.48 & 19.08 & 21.48 & 6.48 \\
\hline \multicolumn{6}{|l|}{ 1969:Q4 to $1970: Q 4$} \\
\hline Average deviation & 0.54 & 4.11 & 1.28 & -12.16 & -14.46 \\
\hline High & 2.47 & 7.92 & 3.68 & 1.44 & -8.64 \\
\hline Low & -1.29 & -0.80 & -2.58 & -32.48 & -22.36 \\
\hline High - Low & 3.76 & 8.72 & 6.26 & 33.92 & 13.72 \\
\hline \multicolumn{6}{|l|}{ 1973:Q4 to 1975:Q1 } \\
\hline Average deviation & 3.97 & 7.18 & 8.73 & -0.24 & -12.82 \\
\hline High & 7.92 & 9.29 & 13.25 & 12.73 & 5.32 \\
\hline Low & -3.54 & 3.21 & -3.33 & -18.53 & -35.85 \\
\hline High - Low & 11.46 & 6.09 & 16.59 & 31.26 & 41.17 \\
\hline \multicolumn{6}{|l|}{ 1981:Q3 to 1982:Q4 } \\
\hline Average deviation & 3.93 & -3.92 & -1.96 & -14.43 & -30.22 \\
\hline High & 11.60 & 2.55 & 3.49 & -2.99 & -13.44 \\
\hline Low & -4.24 & -15.29 & -10.70 & -27.08 & -40.88 \\
\hline High - Low & 15.83 & 17.84 & 14.19 & 24.08 & 27.44 \\
\hline \multicolumn{6}{|l|}{ 1990:Q3 to 1991:Q1 } \\
\hline Average deviation & 5.35 & -0.95 & -1.58 & 0.14 & -13.33 \\
\hline High & 8.20 & 0.14 & 1.53 & 2.78 & -5.76 \\
\hline Low & 3.26 & -3.07 & -4.03 & -1.41 & -20.73 \\
\hline High - Low & 4.94 & 3.21 & 5.56 & 4.20 & 14.97 \\
\hline \multicolumn{6}{|l|}{ 2001:Q1 to 2001:Q4 } \\
\hline Average deviation & -2.52 & -7.22 & -2.95 & -10.50 & -1.88 \\
\hline High & 2.06 & 1.66 & 4.92 & -7.57 & -0.52 \\
\hline Low & -10.76 & -13.68 & -9.92 & -13.08 & -3.63 \\
\hline High - Low & 12.82 & 15.34 & 14.84 & 5.50 & 3.11 \\
\hline
\end{tabular}

NOTE: Percentages are calculated as deviations from trend in chain-weighted dollars. The trend value is estimated from the HodrickPrescott algorithm. See footnote 5. Sample period for Hodrick-Prescott calculations are 1947:Q1 to 2001:Q4 for all categories except IPES, which begins in 1959:Q1. 
mainframe computer code Y2K compliant. Bureau of Economic Analysis methodology stipulates that "software-related expenditures treated as investment exclude maintenance and repair expenditures on existing software, including expenditures to fix so-called 'Y2K' problems." Accordingly, if Firm A reports these receipts as software maintenance and repair, then there would be no corresponding increase in software investment. However, if Firm A reports these receipts as custom programming services (custom software), then the effect is an increase in software investment. ${ }^{18}$

Scenario 2. The same rationale holds if, instead of contracting out the services in question, the firm decided to hire additional workers for the task (own-account software). In either case, though, the $\$ 10$ million in wages and salaries paid to the employees would show up on the income side of the NIPA. Thus, whether the $\$ 10$ million shows up as a final output on the product side or is treated as an intermediate expense on the product side, depends on how these receipts are reported. ${ }^{19}$

Scenario 3. Finally, assume instead that Firm A decided to purchase new software (prepackaged software) or new Y2K-compliant computers that included embedded software. In this case, the new equipment or software would be classified as new investment even if the equipment or software it replaced was fully depreciated. Fully ascertaining what is a final product and what is an intermediate expense is probably not possible because of data limitations. That is, U.S. statistical agencies such as the Bureau of Economic Analysis and the Bureau of the Census have not published estimates of Y2Krelated spending. There are estimates, however, that have been pieced together with the help of private consultants. For example, the U.S. Department of Commerce's Economics and Statistics Administration, with the assistance of the International Data Corporation, reported that nearly half (46 percent) of worldwide Y2K spending reflected "internal" efforts to "identify and diagnose the problem, espe-

\footnotetext{
${ }^{18}$ In the NIPA, there are three types of software treated as a fixed investment: prepackaged, custom, and own-account. See Bureau of Economic Analysis (2000). In non-benchmark years, investment for prepackaged and custom software are extrapolated using industry receipts rather than product-type receipts. For example, the Bureau of Economic Analysis uses services receipts for a firm that classifies itself as a custom software establishment to extrapolate (using the input-output accounts) the NIPA output for custom software. The last input-output benchmark is for 1992 .

${ }^{19}$ In the NIPA, it is assumed that intermediate expenses eventually show up in final output.
}

cially in the case of embedded chips." 20 This fraction is only a little more than a quarter (27 percent) of total reflected "external" spending. Expenditures on hardware (11 percent) and software (17 percent) were also a little more than a quarter of the total spending. Assuming that these percentages apply to the United States and that they accurately reflect the distribution of spending, then only about half of total Y2K expenditures probably flowed into the output of final goods and services, with the remainder slotted as intermediate expenses. ${ }^{21}$

\section{Y2K Cost Estimates}

In testimony before the U.S. Senate Committee on Commerce, Science, and Transportation, (then) Federal Reserve Governor Edward Kelley noted that a survey of corporate 10-K financial reports filed with the Securities and Exchange Commission by Federal Reserve Board staff economists indicated that "an educated guess of the sunk cost of Y2K remedial efforts in the U.S. private sector might be roughly $\$ 50$ billion." 22 The aforementioned Economics and Statistics Administration report, citing the study commissioned by the International Data Corporation in October 1999, estimated that the cost of public- and private-sector $\mathrm{Y} 2 \mathrm{~K}$ spending in the United States from 1995 to 2001 was expected to total $\$ 114$ billion. ${ }^{23}$ In inflation-adjusted terms, as Table 4 indicates, this amounted to roughly $\$ 131$ billion.

If the numbers in Table 4 are a reasonable approximation of the actual Y2K-related spending that occurred, then the efforts of U.S. firms to ready themselves for the century date change totaled a bit less than 1.5 percent of GDP over this six-year period. While fairly significant, it hardly seems to have been a major event expenditure-wise, given that it was spread out over several years. Second, if, as conjectured above, only about half of Y2K expenditures flowed into final output, then the potential Y2K-related investment contribution to real GDP

\footnotetext{
${ }^{20}$ See Economic and Statistical Administration (1999, pp. 3-4).

21 A further complication is that, unlike the estimates of prepackaged and custom software investment described in footnote 18 (commodity flow method), own-account software investment is measured as the sum of production costs (wage and non-wage) and the costs of intermediate inputs. See Bureau of Economic Analysis (2000).

22 <www.federalreserve.gov/boarddocs/testimony/1998/19980428.htm >

23 The Economic and Statistical Administration admitted that this estimate was not precise. Accordingly, they place a confidence interval of $\$ 50$ billion around either side of their point estimate.
} 


\section{Table 4}

\section{Real Y2K Spending and the Change in Real Fixed Investment in Information Processing} Equipment and Software

\begin{tabular}{|c|c|c|c|c|c|c|}
\hline \multirow[b]{3}{*}{ Year } & \multirow{2}{*}{\multicolumn{2}{|c|}{ Billions of dollars }} & & & \multicolumn{2}{|c|}{ Percentage points } \\
\hline & & & \multicolumn{2}{|c|}{ Percent } & \multirow{2}{*}{$\begin{array}{c}\text { IPES } \\
\text { contribution to } \\
\text { real GDP growth }\end{array}$} & \multirow{2}{*}{$\begin{array}{c}\text { Potential Y2K } \\
\text { contribution to } \\
\text { real GDP growth }\end{array}$} \\
\hline & Y2K & IPES & Y2K/IPES & IPES/GDP & & \\
\hline 1995 & 4.3 & 36.2 & 11.8 & 3.5 & 0.56 & 0.07 \\
\hline 1996 & 15.5 & 44.5 & 34.8 & 3.7 & 0.62 & 0.22 \\
\hline 1997 & 29.4 & 62.5 & 47.0 & 3.9 & 0.77 & 0.36 \\
\hline 1998 & 37.7 & 79.5 & 47.4 & 4.1 & 0.85 & 0.40 \\
\hline 1999 & 36.5 & 78.8 & 46.3 & 4.3 & 0.73 & 0.34 \\
\hline 2000 & 6.8 & 75.2 & 9.0 & 4.5 & 0.63 & 0.06 \\
\hline 2001 & 0.8 & -34.8 & -2.3 & 4.0 & -0.26 & 0.01 \\
\hline Sum: 1995-2001 & 130.9 & 341.9 & $\mathrm{~N} / \mathrm{A}$ & $\mathrm{N} / \mathrm{A}$ & 3.90 & 1.45 \\
\hline
\end{tabular}

NOTE: Estimates for 1999-2001 are projections. Real Y2K spending is the current-dollar value of spending deflated by the chain-type price index for IPES. Sums subject to rounding.

SOURCE: Economics and Statistics Administration, Bureau of Economic Analysis, Haver Analytics, and the author's calculations (final column).

growth was much less, about 0.75 percentage points (half of 1.45 percent). Finally, the bulk of the Y2Krelated spending occurred from 1997 to 1999 (\$103.6 billion). Accordingly, the timing of the expenditures suggests that the surge in IPES investment that peaked in the fourth quarter of 2000 was probably not driven by Y2K expenditures. Thus, while the investment boom and bust was probably exacerbated by Y2K remediation efforts (and their subsequent cessation), it was more likely the result of declines in the equity cost of capital or other business cycle effects. ${ }^{24}$ This conclusion is similar to that reached by the Bank of England, which reported that in March 2000 only "a small minority of companies were planning much lower IT investment over the next two years than in the previous two years." 25

\section{CONCLUSION}

A salient feature of the business cycle that spanned from March 1991 to the end of 2002 (the National Bureau of Economic Research Committee has yet to identify the trough) was the high-tech

\footnotetext{
24 Macroeconomic Advisers (2002) found "weak evidence" of a Y2K boost to real software investment.

25 Bakhshi and Thompson (2002).
}

investment boom and bust. Several explanations have been offered for this development, including the acceleration in labor productivity - the so-called "New Economy" story - and the stock market surge and subsequent collapse. One explanation that has not been scrutinized in detail was the spending by businesses to ready themselves for the century date change. Because many information processing systems and much of the hardware and software were not Y2K compliant as late as early 1998, it was thought that business investment in high-tech $\mathrm{E} \& \mathrm{~S}$ would increase appreciably to fix this problemhence, leading to a Y2K-related investment boom in the late 1990s. Although solid data are lacking, the evidence presented in this paper indicates that the investment boom and bust was more than a Y2K event.

\section{REFERENCES}

Bachula, Gary R. "The Year 2000 (Y2K) Computer Problem.” Forum on the Year 2000 Y2K Computer Problem, hosted by Senator Olympia Snowe, 31 July 1998.

<www.ta.doc.gov/speeches/y2k.htm > .

Bakhshi, Hasan and Thompson, Jamie. "Explaining Trends in UK Business Investment." Bank of England Quarterly Bulletin, Spring 2002, 42(1), pp. 33-41. 
Bureau of Economic Analysis. "Recognition of Business and Government Expenditures for Software as Investment: Methodology and Quantitative Impacts, 1959-98." Unpublished manuscript, May 2000. <www.bea.gov/ bea/papers/software.pdf $>$.

Council of Economic Advisers. Economic Report of the President, Washington, DC: U.S. Government Printing Office, February 1999 and February 2002.

Economics and Statistics Administration, United States Department of Commerce. "The Economics of Y2K and the Impact on the United States.” 17 November 1999.

French, Eric; Klier, Thomas and Oppedahl, David. "Is There Still an Investment Overhang, and If So, Should We Worry About It?" Federal Reserve Bank of Chicago Fed Letter, May 2002.

Greenspan, Alan. Testimony before the Committee on Banking, Housing, and Urban Affairs, U.S. Senate. Board of Governors of the Federal Reserve System, 21 July 1998.

Macroeconomic Advisers. Economic Outlook. 20 May 2002 and 21 June 2002.

Matthews, Gordon. "Deutsche Bank Economist Sees 70\% Chance Year-2000 Glitch Will Cause Severe Recession." American Banker, 6 July 1998, pp. 33-34.

McCarthy, Jonathan. "Equipment Expenditures Since 1995: The Boom and the Bust." Federal Reserve Bank of New York Current Issues in Economics and Finance, October 2001, 7(9), pp. 1-6.

Pakko, Michael R. "The High-Tech Investment Boom and Economic Growth in the 1990s: Accounting for Quality," Federal Reserve Bank of St. Louis Review, March/April 2002, 84(2), pp. 3-18.

Stiroh, Kevin J. "Information Technology and the U.S. Productivity Revival: A Review of the Evidence." National Association for Business Economics Business Economics, January 2002, 37(1), pp. 30-37.

Whelan, Karl. "A Guide to the Use of Chain Aggregated NIPA Data." Working Paper 2000-35, Finance and Economics Discussion Series, Federal Reserve Board of Governors, June 2000. 